\title{
Maternal thrombophilia and neonatal thrombosis
}

\author{
Christine Heller MD \\ Paediatric Haematology/Oncology, University Hospital of Frankfurt, Germany \\ Ulrike Nowak-Göttl* MD \\ Paediatric Haematology/Oncology, University Hospital of Münster, Germany
}

\begin{abstract}
In neonates and infants, numerous clinical and environmental conditions lead to elevated thrombin generation and subsequent thrombus formation. Genetic prothrombotic defects (protein C, protein S and antithrombin deficiency, mutations of coagulation factor $\mathrm{V}$ and factor II, elevated lipoprotein (a)) have been established as risk factors of thromboembolic events in neonates and infants. The interpretation of the laboratory evaluation relies on age-dependent normal reference values. Because appropriate clinical trials are missing in these age groups, treatment recommendations are adapted from small-scale studies in neonates and infants and from guidelines relating to adult patient protocols. Secondary long-term anticoagulation should be administered on an individual basis.
\end{abstract}

Key words: neonatal thrombosis; underlying diseases; prothrombotic risk factors; therapy.

Thrombotic events in the neonatal period are a serious clinical condition with an estimated incidence of approximately $2.4 / 1000$ admissions of newborns to intensive care units in the white population. ${ }^{1-4}$ Although the presentation of thrombosis is quite rare, this entity is increasing in frequency because of more sensitive diagnostic procedures and greater clinical awareness. Within the entire childhood population, possibly due to the lower concentrations of antithrombin, heparin cofactor II and protein $\mathrm{C}$ along with a reduced fibrinolytic capacity, neonates are at greater risk than older children of thromboembolic complications. ${ }^{4}$ The incidence of vascular accidents decreases significantly after the first year of life, with a second peak during puberty and adolescence, again associated with reduced fibrinolytic activity. Because of the often severe clinical manifestations in neonates with possible long-term morbidity, more studies are necessary to evaluate risks and outcome of thromboembolic events in neonates and infants.

\footnotetext{
* Corresponding author. Address: Münster Department of Paediatric Haematology and Oncology, Westfalische Wilhelms Universitat, Albert SchweitzerStrasse 33, Münster, 48I49, Germany. Tel.: +4925 I8347783; Fax: + 49-2518347828.

E-mail address: leagottl@uni-muenster.de
}

I52 I-6926/03/\$ - see front matter (c) 2003 Elsevier Science Ltd. All rights reserved. 


\section{MATERNAL THROMBOPHILIA}

Obstetric complications such as placental abruption, fetal loss and stillbirth are associated with intervillous or spiral-artery thrombosis, and placental infarction is frequently observed in low-birth-weight children. ${ }^{5-8}$ Previous work on the potential role of prothrombotic risk factors has focused mainly on the maternal side of the placenta and has shown that placental infarction and thrombosis are associated with maternal thrombophilia, i.e. antiphospholipid antibodies, hyperhomocysteinaemia, protein $\mathrm{C}$ deficiency, the heterozygous factor $\mathrm{V}$ GI69IA mutation, the heterozygous factor II variant and increased Lp (a) concentrations. ${ }^{6-9}$ Besides the involvement of inherited or acquired maternal thrombophilic risk factors in fetal wastage, prematurity or intrauterine growth retardation due to placental infarction, and peripartal thromboembolic stroke ${ }^{10-16}$, little is known so far about neonatal thromboembolism possibly associated with maternal thrombophilia. Further studies on the impact of thrombophilia on neonatal thromboembolism therefore have to take into account, in addition, potential interdependencies with maternal thrombophilia.

\section{Practice points}

Pregnant women with a personal history of symptomatic thromboembolism, fetal wastage, prematurity or intrauterine growth retardation should:

- be screened for prothrombotic risk factors

- receive secondary preventive antithrombotic treatment with low-molecular weight heparin on an individual patient basis ${ }^{17,18}$

- undergo regular ultrasound examination (e.g. in gestational weeks $10,20,30$ ) to evaluate fetal growth development and to detect possible intrauterine fetal thrombus formation (caval/renal veins, cerebral arteries/veins) prior to delivery

\section{Research agenda}

No data are available so far with respect to the interaction of maternal and fetal prothrombotic risk factors. Therefore:

- prospective studies are recommended to evaluate the role of thrombophilia in mothers and fetuses and their possible role in obstetric complications, fetal growth restriction and/or fetal/neonatal thrombus formation

- because the role of steroid administration in inducing lung maturation as a 'prothrombotic' drug for the fetus is unclear, this issue should be prospectively studied

\section{DEVELOPMENTAL HAEMOSTASIS}

In general, the haemostatic system in neonates is a balanced physiological system despite low concentrations of plasma coagulation proteins with a prolonged thromboplastin time and a partial thromboplastin time. Some conditions are believed to cause a disturbance between coagulation and fibrinolysis following a prothrombotic state. ${ }^{4}$ It has been shown in various in vivo and in vitro studies that components of the haemostatic system, i.e. vascular endothelium, procoagulant and fibrinolytic factors, differ between infants and adults. ${ }^{419-23}$ Different coagulation factors show different 
Table I. Age-dependent reference values (median, range); healthy neonates and children ${ }^{36}$.

\begin{tabular}{|c|c|c|c|c|c|c|}
\hline Factor (\%) & 0-30 Days & 3 Months & 6 Months & I-5 Years & 6-9 Years & $10-18$ Years \\
\hline $\begin{array}{l}\text { Protein } \\
\text { C-Act }\end{array}$ & $35(14-55)$ & $55(25-82)$ & $60(38-95)$ & $75(45-102)$ & $84(64-125)$ & $88(62-128)$ \\
\hline $\begin{array}{l}\text { Protein } \\
\mathrm{C} \mathrm{Ag}\end{array}$ & $30(12-50)$ & $50(22-75)$ & $55(40-100)$ & $70(45-98)$ & $80(55-120)$ & $82(55-120)$ \\
\hline $\begin{array}{l}\text { Free prot. } \\
\mathrm{S} \mathrm{Ag}\end{array}$ & $38(15-55)$ & 55 (35-92) & $77(45-115)$ & $78(62-120)$ & $80(62-130)$ & $85(60-140)$ \\
\hline $\begin{array}{l}\text { Total prot. } \\
\mathrm{S} \mathrm{Ag}\end{array}$ & $35(14-55)$ & $58(35-90)$ & $75(50-110)$ & $85(60-120)$ & $82(59-118)$ & $80(60-115)$ \\
\hline $\begin{array}{l}\text { Anti- } \\
\text { thrombin }\end{array}$ & $52(30-85)$ & $90(55-120)$ & $98(65-126)$ & $101(85-140)$ & $100(85-136)$ & $98(84-139)$ \\
\hline $\begin{array}{l}\text { Plasmi- } \\
\text { nogen }\end{array}$ & $50(35-70)$ & $68(45-95)$ & $87(65-100)$ & $98(63-123)$ & $95(68-120)$ & $90(70-115)$ \\
\hline $\begin{array}{l}\text { Homo- } \\
\text { cysteine }\end{array}$ & $<10 \mu \mathrm{mol} / \mathrm{l}$ & & & & & \\
\hline $\begin{array}{l}\text { Lp (a) } \\
\mathrm{mg} / \mathrm{dl} / \\
\mathrm{kringle} \\
4 \text { repeats }\end{array}$ & $<(20) 30 \mathrm{mg} /$ & $d \mathrm{dl}>28$ & & & & \\
\hline
\end{tabular}

postnatal patterns of maturation. In the newborn, plasma concentrations of the vitamin K-dependent coagulation factors (II, VII, IX, X), contact factors (XI, XII, prekallikreine and high-molecular weight kininogen) are approximately $50 \%$ of adult values. These levels undergo a rapid increase in the first weeks of life, and coagulation protein values equivalent to adult values are achieved in most components by 6 months of age. In addition, the vitamin K-dependent natural inhibitors protein $\mathrm{C}$ and protein $\mathrm{S}$ are low in the neonatal period (Table I). However, despite reduced total protein $S$ antigen levels in neonatal plasma, a relatively high level of active protein $\mathrm{S}$ was found due to virtually undetectable levels of C4b-binding protein, suggesting a minimized risk of vascular accidents. $^{20}$ Antithrombin, heparin cofactor II and protein $\mathrm{C}$ are reduced to approximately $50 \%$ of that of adults, whereas alpha- 2 macroglobulin is increased over adult values at birth, reaching twice adult values by 6 months of age. ${ }^{19,21}$ Furthermore, the decreased capacity of newborn plasma to generate thrombin is dependent mainly on plasma concentrations of prothrombin, a fact that is therefore discussed as a source of further protection from thrombotic events during infancy and childhood. Whereas the characteristics of some components of the procoagulant coagulation system may contribute to a reduced risk of thromboembolism during infancy, there is no evidence that fibrinolytic proteins provide protection from vascular accidents in the very young. In the neonatal period, despite increased concentrations of tissue type plasminogen activator (t-PA), the decreased plasma levels and activity of plasminogen and the increased concentration of tissue type plasminogen activator inhibitors (PAI) are responsible for a hypofibrinolytic state. This situation also accounts for the prolonged thrombus lysis times observed in neonates in response to urokinase and to streptokinase and tissue type plasminogen activator (high concentrations only) administration. ${ }^{23}$ 


\section{Practice points}

- keep in mind the age-dependent reference values for plasma-based coagulation factors

\section{THROMBOTIC LOCATIONS IN NEONATES AND INFANTS}

The most common sources of thrombus formation in neonates (Table 2) are the renal veins, vena caval occlusion, cerebral venous thrombosis, and peripartal thromboembolic stroke. In addition, high rates of catheter-related thrombosis have been reported in neonates and infants. ${ }^{1,2}$ Further reported sources are portal and mesenteric vein thrombosis, while arterial vascular occlusions have been reported mainly as ischaemic stroke, and as catheter-related thrombosis in the aorta, the femoral artery and the subclavian artery, respectively. A further rare and lifethreatening thrombotic disorder 'purpura fulminans', characterized by initial microvascular thrombosis in the dermis followed by perivascular haemorrhage, is observed within hours of birth in neonates with disseminated intravascular coagulation in response to septicaemia, and in babies carrying homozygous protein $\mathrm{C}$ deficiency or homozygous protein $\mathrm{S}$ deficiency.

\section{CLINICAL SYMPTOMS AT THROMBOEMBOLIC ONSET}

Clinical symptoms of deep venous thrombosis include oedema and cyanosis of the dependent limb(s), head, neck or chest, and collateral vessel circulation; abdominal mass, thrombocytopenia or haematuria give evidence of renal venous thrombosis. ${ }^{1-4}$ Acute catheter-related thrombosis includes 'blockage' of the central venous line (CVL) along with swelling, pain and discoloration of the involved limb, and chronic CVLrelated thrombosis often presents with collateral circulation. Respiratory failure,

Table 2. Locations of venous and arterial thrombosis in neonates.

Venous

Arterial

Deep vein thrombosis of the limbs
Pulmonary embolism
Renal veins
Hepatic veins
Caval veins
Right intracardiac thrombosis
Portal vein
Mesenteric veins
Cerebral veins
Retinal vein
Ischaemic stroke
Aorta
Left intracardiac
Renal artery
Mesenteric artery
Limb artery


dyspnoea and tachypnoea give evidence of pulmonary embolism. Arterial thromboses of the limbs present clinically with cold, pale limbs along with diminished or absent pulses, diminished peripheral perfusion or reduced skin temperature. Seizures, hemiparesis and coma are leading symptoms of vascular accidents within the central nervous system in the neonate and young infant.

\section{DIAGNOSTIC IMAGING METHODS}

In general, the diagnostic procedures are more difficult to perform in neonates than in adult patients because of frequent clinical instability and the lack of comparable data concerning ultrasonographic scans. Duplex sonography, venography, computed tomography and magnetic resonance (MR) imaging can be used to diagnose venous thrombosis. However, venography is mandatory to confirm suspected thrombosis in the upper venous system (axillary veins, superior caval veins etc). MR imaging and MR angiography are recommended to confirm the diagnosis of thromboembolic ischaemic stroke. Ventilation/perfusion scan or MR angiography are suitable methods for diagnosing pulmonary embolism in children.

\section{Research agenda}

- controlled studies are suggested to establish 'gold standards' for imaging methods in neonates with thromboembolism

\section{ACQUIRED AND INHERITED PROTHROMBOTIC CONDITIONS}

Thrombus formation and thrombus growth are the result of local coagulation activation combined with a disturbance in the balance between coagulation and fibrinolysis, leading to a prothrombotic state. Numerous conditions such as peripartal asphyxia, fetal diabetes, neonatal infections, dehydration, the use of central lines, trauma or surgery, malignant diseases, renal diseases or autoimmune diseases result in elevated thrombin generation with subsequent thrombus formation in neonates and infants (Table 3; Refs. 24-30).

Various genetic defects, particularly those affecting the physiological anticoagulant systems, i.e. antithrombin, protein $\mathrm{C}$, and protein $\mathrm{S}$ deficiency, resistance to activated protein C (APC-R) mostly due to the GI69/A mutation of coagulation factor $V$, and the factor II G20210A gene variant, have been well established as risk factors for thrombotic events (Table 4; Refs. 3I-45). In addition, metabolic diseases such as homozygous homocystinuria, and moderate hyperhomocysteinaemia due to malnutrition or the common homozygous TT genotype of the methylenetetrahydrofolate reductase (MTHFR) C677T polymorphism ${ }^{46,47}$ have been described, as well as increased concentrations of lipoprotein (LP) (a), which have been recently shown significantly to enhance the risk of thromboembolic arterial and venous thrombosis in paediatric patients. ${ }^{48}$ Thrombophilia is a multifactorial disorder, and the presence of more than one haemostatic defect or the combination of hereditary risk factors with acquired environmental or clinical 
Table 3. Underlying acquired risk factors in neonates with thrombosis.

\begin{tabular}{|c|c|}
\hline \multirow[t]{8}{*}{ Perinatal diseases } & Birth asphyxia \\
\hline & Respiratory distress syndrome \\
\hline & Infants of diabetic mothers \\
\hline & Neonatal infections \\
\hline & Necrotising enterocolitis \\
\hline & Dehydration \\
\hline & Congenital nephritic syndrome \\
\hline & Polycytemia \\
\hline \multirow[t]{6}{*}{ Medical interventions } & Central lines \\
\hline & Operations \\
\hline & Renal transplantation \\
\hline & Immobilization \\
\hline & Plaster casts \\
\hline & Extracorporeal membrane oxygenation \\
\hline \multirow[t]{6}{*}{ Acute diseases } & Trauma \\
\hline & Sepsis \\
\hline & Dehydration \\
\hline & Acute rheumatic diseases \\
\hline & Nephrotic syndrome \\
\hline & Acute lymphoblastic leukaemia \\
\hline \multirow[t]{4}{*}{ Chronic diseases } & Malignancies \\
\hline & Renal diseases \\
\hline & Cardiac malformations \\
\hline & Chronic rheumatic diseases \\
\hline \multirow[t]{5}{*}{ Drugs } & E. coli asparaginase \\
\hline & Prednisone \\
\hline & Coagulation factor concentrates \\
\hline & Heparins \\
\hline & Antifibrinolytic agents \\
\hline
\end{tabular}

conditions greatly increases the risk of thrombosis not only in adults but also in neonates and infants.

Moreover, acquired antiphospholipid antibodies play a potential role in the paediatric population with symptomatic venous thrombosis ${ }^{49}$ or ischaemic cerebrovascular accidents. ${ }^{39}$ Rare disorders of the haemostatic system, for example dysfibrinogenaemia, hypo- or dysplasminogenaemia, heparin cofactor II deficiency, increased levels of histidine-rich glycoprotein or further genetic polymorphisms were also found to be associated with the risk of venous thrombosis.

\section{Practice points}

- as neonatal thromboembolism is a multifactorial disorder look for underlying diseases and prothrombotic risk factors 
Table 4. Inherited prothrombotic risk factors.

\begin{tabular}{ll}
\hline & Prothrombotic risk factors \\
\hline Common & Factor V GI69IA gene mutation \\
& Factor II G202IOA gene mutation \\
& Increased concentrations of apolipoprotein (a) \\
& Moderate hyperhomocysteinemia \\
& Homozygous C677T polymorphism in the \\
& methylenetetrahydrofolate reductase gene \\
& Protein C deficiency \\
Rare & Protein S deficiency \\
& Antithrombin deficiency \\
& Heparin cofactor II deficiency \\
Very rare & Dysfibrinogenaemia \\
& Dys/hypoplasminogenaemia \\
Probably inherited & Homozygous homocystinuria \\
& Increased levels of factor VIIIC, IX, or fibrinogen \\
& Decreased levels of factor XII \\
\hline
\end{tabular}

\section{SCREENING FOR PROTHROMBOTIC RISK FACTORS IN NEONATES AND INFANTS}

Suitable protein-based assays for determination of APC-R, protein C, protein S and antithrombin activity, concentration of clottable fibrinogen, plasminogen activity, activities of coagulation factors VIIIC and XII, LP(a), histidine-rich glycoprotein, heparin cofactor II, and fasting homocysteine concentrations should be investigated along with DNA-based assays, i.e. factor V GI69IA mutation, factor II G20210A variant and MTHFR C677T genotype.

A step-wise diagnostic procedure is recommended for plasma-based parameters because the corresponding antigen concentration is not reduced when the activity of a protein is within its normal range. ${ }^{36,50}$ In patients with reduced protein activity, the total and free (protein S only) protein concentration should be determined.

Besides testing for prothrombotic defects as stated above, all symptomatic neonates with thrombosis should be screened for antiphospholipid antibodies and the presence of lupus anticoagulants. In addition, because a recent prospective study on recurrent vascular occlusion after a first episode of spontaneous venous thromboembolism, i.e. thrombosis in the absence of further secondary causes, has identified a subgroup of children suffering from combined prothrombotic risk factors as being at high risk of recurrent thrombosis, ${ }^{45}$ a search for multiple risk factors is justified.

\section{WHEN SHOULD TESTING BE DONE?}

To prevent results of protein-based assays from being affected by the acute thrombotic onset, plasma samples should be obtained at least 3-6 months after the thrombotic episode. In addition, oral anticoagulant medication also influences protein-based assays. 
Therefore it is recommended that fresh plasma samples for coagulation analyses should be drawn at least 14-30 days after withdrawal of oral anticoagulation. In contrast, because DNA-based assays are influenced neither by the acute thrombotic onset nor by anticoagulation and thrombolytic therapy, genotyping can be performed immediately on onset of the vascular accident. Because $L p(a)$ levels increase during the first year of life, reaching twofold values compared with birth values at the age of approximately I year, repeat testing 8-12 months after the acute thrombotic onset is mandatory when including $L p(a)$ in the screening program of Caucasian neonates suffering from thromboembolism. ${ }^{51}$ Repeat testing is also necessary in paediatric patients with increased anticardiolipin/antiphospholipid IgG antibodies or with lupus anticoagulants.

\section{CRITERIA FOR DIAGNOSIS}

For all plasma-based assays, a clotting abnormality should be documented as a defect only if the plasma level of a protein is outside the limits of its normal range (Table I; Refs. 36,50) Besides classification based on age-dependent normal reference ranges and confirmation of a suspected protein-based prothrombotic defect in a second plasma sample, the criterion for the hereditary nature of a haemostatic risk factor is the identification of a causative gene mutation. ${ }^{52}$

A type I deficiency state can be diagnosed when the functional plasma activity and immunological antigen concentration of a protein is below the age-related limit. A type II deficiency is present when repeatedly low functional activity levels are combined with normal antigen concentrations. As in adults ${ }^{52}$, the diagnosis of protein S deficiency is based on reduced free protein $S$ antigen levels combined with decreased or normal total protein $S$ antigen concentrations in children with pre-diagnosed reduced protein $S$ activities.

\section{Practice points}

As the distribution of prothrombotic risk factors varies in different countries with respect to ethnic backgrounds and the number of patient/controls investigated:

- screen beyond the acute thrombotic onset for plasmatic prothrombotic risk factors

- investigate in comparison with age- and gender-matched healthy controls from the same geographic catchment areas

\section{Research agenda}

Because there are only sparse data available to date with respect to the presence of inherited prothrombotic risk factors in paediatric populations, recommendations given in the text are restricted to white German and Austrian children with venous thrombosis or stroke.

- case-control studies are recommended for evaluating the role of prothrombotic risk factors in other populations 


\section{Research agenda}

Long-term follow-up studies are recommended to evaluate:

- the rate of secondary thrombosis.

- the development of post-thrombotic syndromes/organ damage

\section{CLINICAL OUTCOME}

Clinical follow-up studies of paediatric patients with thromboembolic vascular accidents have been reported for renal venous thrombosis, vena caval occlusion, deep venous thrombosis and pulmonary embolism. ${ }^{53-56}$ Renal venous thromboses and vena caval occlusion occurring in neonates and infants frequently persist and lead to considerable long-term morbidity with a high incidence of irreversible organ damage, i.e. residual structural abnormalities, renal function impairment and hypertension. ${ }^{54}$

\section{ANTITHROMBOTIC THERAPY IN NEONATES: GENERAL COMMENTS}

Currently, only limited data are available on the treatment and prevention of thrombotic events in neonates. ${ }^{57}$ Thus, recommendations for antithrombotic therapy in this special patient cohort are available only from small-scale studies of children or are adapted from adult protocols. At acute onset of thrombosis, anticoagulation should be initiated to achieve patency of the occluded vessel and to prevent further thrombus growth. Anticoagulants used in neonates and infants are standard heparin (Table 5), low-molecular weight heparin (Table 6; Refs. 57-59) and thrombolytic agents ${ }^{60-67}$ The therapeutic choice is influenced individually by the clinical situation of the child, the risk of a major bleeding complication, and the extent and location of the thrombus, respectively.

\section{Acute thrombotic therapy}

Besides specific treatment of acute thromboembolism with anticoagulant or thrombolytic therapy (catheter- and non-catheter-related thrombosis), infants with acute purpura fulminans due to homozygous protein $C$ deficiency or protein $S$ deficiency should receive fresh frozen plasma or, if available, protein $C$ concentrate. ${ }^{68,69}$ As in adults, it has to be kept in mind that heparin administration as well as the use of thrombolytic agents can lead to major bleeding episodes or to acute thrombus rupture with subsequent pulmonary embolism or thromboembolic stroke in neonates (patent foramen ovale). In addition, heparin-induced thrombocytopenia type II has been reported not only in adults but also in paediatric patients, creating the potential need to substitute heparin with an alternative anticoagulant emergently. ${ }^{70}$ Although evidence-based data are missing, the management of neonates and infants with life-threatening thrombosis possibly leading to organ or limb damage necessitates acute thrombotic treatment, for example thrombolytic therapy. ${ }^{60}$ 
Table 5. Bodyweight-adjusted systemic unfractionated heparin (UFH) administration (own data and Ref. 57) (A) loading dose, 50- 100 units/kg UFH i.v. over 10 minutes; (B) maintenance, $20-30$ units $/ \mathrm{kg} / \mathrm{hour}$ UFH; (C) adjustment, APTT 55-90 seconds (normal range of APTT reagent: 25-38 seconds) or 4 hours anti- factor Xa level: $0.4-0.8$ units $/ \mathrm{ml}$.

\begin{tabular}{lccc}
\hline APTT (seconds) & Bolus (units $/ \mathrm{kg})$ & Stop infusion & Rate change (\%) \\
\hline$<55$ & 0 & - & +10 \\
$56-90$ & 0 & - & 0 \\
$91-120$ & 0 & - & -10 \\
$>120$ & 0 & 1.5 hours & -15 \\
\hline
\end{tabular}

APTT/anti-factor Xa level-control: 4 hours after loading dose and after increase or reduction of dosage. Cave HIT type II: complete blood cell count required daily; dose reduction in patients with reduced hepatic or renal function.

Table 6. Bodyweight-adjusted low molecular weight heparin (LMWH: e.g. enoxaparin) administration for paediatric patients (own data and Refs. 57,58).

\begin{tabular}{|c|c|c|}
\hline \multicolumn{2}{|l|}{ Neonates } & \multirow{2}{*}{$\begin{array}{l}\text { 4-Hour anti-factor } \text { Xa level } \\
0.2-0.4 \text { units/ml; monitoring after dose-finding } \\
\text { not necessarily required }\end{array}$} \\
\hline Prophylactic & $\mathrm{I} \times 1.5 \mathrm{mg} / \mathrm{kg} /$ daily & \\
\hline Therapeutic & $2 \times 1.5 \mathrm{mg} / \mathrm{kg} /$ daily & $0.4-0.8$ units $/ \mathrm{ml}$ monitoring required \\
\hline
\end{tabular}

Enoxaparin (Clexane ${ }^{\circledR}$ ) contains 110 anti-factor $\mathrm{Xa}$ units $/ \mathrm{mg}$; maximum single dose $2.0 \mathrm{mg} / \mathrm{kg}$.

\section{Long-term antithrombotic treatment}

To the current state of knowledge only few authors have reported on the outcome of paediatric patients with venous thromboembolism. Until prospective randomized data on long-term anticoagulation in neonates and infants are available, children in this age group should be treated on an individual basis. Neonates with venous thromboembolism found to have one single prothrombotic trait (one heterozygous allele: factor $\mathrm{V}$ I69IGA, factor II 202 I0GA, deficiencies of protein C, protein S or antithrombin, elevated lipoprotein (a)) should receive oral anticoagulation ${ }^{71}$ or low-dose heparin, usually administered for 3-6 (to 12) months after the acute thrombotic onset. For selected infants and children under long-term coumadin therapy, INR home monitoring is available. In neonates with arterial vascular occlusion or ischaemic stroke we suggest administering low-dose aspirin or $\mathrm{LMWH}^{72}$

\section{Practice points}

- 3 months anticoagulation is suggested when the thrombus is resolved, the provoking factor is gone, and there is no further underlying prothrombotic tendency

- 6-12 (or maybe 24) months may be considered for children with ongoing underlying prothrombotic conditions, such as genetic risks, infections, inflammations or malignancies 
- symptomatic neonates with severe or multiple genetic thrombotic traits (protein C, protein S, antithrombin deficiency) with spontaneous thrombosis, i.e. without further underlying prothrombotic triggering factors, or with a history of life-threatening recurrent thrombosis, long-term anticoagulant therapy with vitamin $\mathrm{K}$-antagonists are considered on an individual patient basis

- secondary preventive anticoagulant therapy, e.g. low-molecular-weight heparin, may be given in situations known to provoke thrombosis

\section{Research agenda}

- prospective and randomized studies are recommended for thrombotic treatment in neonates and infants

\section{REFERENCES}

I. Schmidt B \& Andrew M. Neonatal thrombosis: report of a prospective Canadian and international registry. Pediatrics 1995; 95: 936-943.

2. Nowak-Göttl U, von Kries R \& Göbel U. Neonatal symptomatic thromboembolism in Germany: two year survey. Archives of Disease in Childhood 1997; 76: FI63-FI67.

3. van Ommen $\mathrm{H}$, Heijboer $\mathrm{H}$, Büller $\mathrm{HR}$ et al. Venous thromboembolism in childhood: a prospective twoyear registry in The Netherlands. Journal of Pediatrics 200I; I39: 676-68I.

4. Andrew M. Developmental hemostasis: relevance to thromboembolic complications in pediatric patients. Thrombosis and Haemostasis 1995; 74: 4I5-425.

5. Salafia CM, Vintzileos AM, Silberman $L$ et al. Placental pathology of idiopathic intrauterine growth retardation at term. American Journal of Perinatology 1992; 9: 179- I84.

* 6. Brenner B, Sarig G, Wiener Z et al. Thrombophilic polymorphisms are common in women with fetal loss without apparent cause. Thrombosis and Haemostasis 1999; 82: 6-9.

7. Dizon-Townson DS, Meline L, Nelson LM et al. Foetal carriers of the factor $\mathrm{V}$ Leiden are prone to miscarriage and placental infarction. American Journal of Obstetrics and Gynecology 1997; I 77: 402-405.

8. Berg K, Roland B \& Sande H. High Lp(a) lipoprotein level in maternal serum may interfere with placental circulation and cause fetal growth retardation. Clinical Genetics 1994; 46: 52-56.

9. Pabinger I, Grafenhofer H, Kaider A et al. Preeclampsia and fetal loss in women with a history of venous thromboembolism. Arteriosclerosis, Thrombosis and Vascular Biology 200 I; 2 I: 874-879.

10. Göpel W, Kim D \& Gortner L. Prothrombotic mutations as a risk factor for preterm birth. Lancet 1999; 353: $|4||-| 4 \mid 2$.

II. Verspyck E, Le Camp-Duchez V, Gravier A et al. Small for gestational age infant in association with maternal prothrombin gene variant (nt 20210A). European Journal of Obstetrics and Gynecology and Reproductive Biology 1999; 83: 143-144.

* 12. Kries von R, Junker R, Oberle D et al. Foetal growth restriction in children with prothrombotic risk factors. Thrombosis and Haemostasis 200I; 86: 1012-1016.

13. Vries de LS, Eken P \& Groenendaal F. Antenatal onset of haemorrhagic and/or ischaemic lesions in preterm infants: prevalence and associated obstetric variables. Archives of Disease in Childhood 1998; 78: F5I-F56.

14. Kraus FT \& Acheen VI. Fetal thrombotic vasculopathy in the placenta: cerebral thrombi and infarcts, coagulopathies, and cerebral palsy. Human Pathology 1999; 30: 759-769.

15. Debus O, Koch HG, Kurlemann G et al. Factor V Leiden and genetic defects of thrombophilia in childhood porencephaly. Archives of Disease in Childhood 1998; 78: FI2I-FI24.

16. Govaets $\mathrm{P}$, Matthys E, Zecic A et al. Perinatal cortical infarction within middle cerebral artery trunks. Archives Disease in Childhood 2000; 82: F59-F63.

17. Brenner B, Hoffman R, Blumenfeld Z et al. Gestational outcome in thrombophilic women with recurrent pregnancy loss treated by enoxaparin. Thrombosis and Haemostasis 2000; 83: 693-697.

18. Pauzner R, Dulitzki M, Langevitz R et al. Low molecular weight heparin and warfarin in the treatment of patients with antiphospholipid syndrome during pregnancy. Thrombosis and Haemostasis 200I; 86: I379- I 384 . 
19. Ries M, Klinge J \& Rauch R. Age-related reference values for activation markers of the coagulation and fibrinolytic systems in children. Thrombosis Research 1997; 85: 34I-344.

20. Schwarz HP, Muntean W, Watzke $\mathrm{H}$ et al. Low total protein $\mathrm{S}$ antigen but higher protein $\mathrm{S}$ activity due to decreased c4b-binding protein in neonates. Blood 1988; 7I: 562-565.

21. Cvirn G, Gallistl S \& Muntean W. Effects of antithrombin and protein $C$ on thrombin generation in newborn and adult plasma. Thrombosis Research 1999; 93: 183-190.

22. Andrew M, Schmidt B, Mitchell $L$ et al. Thrombin generation in newborn plasma is critically dependent on the concentration of prothrombin. Thrombosis and Haemostasis 1990; 63: 27-30.

23. Ries $M$, Klinge J, Rauch $R$ et al. In vitro fibrinolysis after adding low doses of plasminogen activators and plasmin generation with and without oxidative inactivation of plasmin inhibitors in newborns and adults. Journal of Pediatric Hematology Oncology 1996; I 8: 346-35I.

24. Nowak-Göttl U, Dübbers A, Kececioglu D et al. Factor V Leiden, protein C and lipoprotein (a) in catheter related thrombosis in childhood-a prospective study. Journal of Pediatrics 1997; 13 I: 608-6I2.

25. Vitiello R, McCrindle BW, Nykanen D et al. Complications associated with pediatric cardiac catheterization. Journal of the American College of Cardiology 1998; 32: 1433- 1440.

26. Salonvaara M, Riikonen $P$, Kekomaki $R$ et al. Clinical symptomatic central venous catheter-related deep venous thrombosis in newborns. Acta Paediatrica 1999; 88: 642-646.

27. Boo NY, Wong NC, Zulkifli SS et al. Risk factors associated with umbilical vascular catheter-associated thrombosis in newborn infants. Journal of Paediatrics and Child Health 1999; 35: 460-465.

28. Schwartz DS, Gettner PA, Konstantino MM et al. Umbilical venous catheterization and the risk of portal vein thrombosis. Journal of Pediatrics 1997; I3 I: 760-762.

29. Schlegel N. Thromboembolic risks and complications in nephrotic children. Seminars in Thrombosis and Haemostasis 1997; 23: 27I-280.

30. Sträter R, Vielhaber H, Kassenböhmer R et al. Genetic risk factors of thrombophilia in ischaemic childhood stroke of cardiac origin. A prospective ESPED survey. European Journal of Pediatrics 1999; I58: SI22-SI25.

3I. Manco-Johnson M, Abshire T, Jacobson L \& Marlar R. Severe neonatal protein C deficiency: prevalence and thrombotic risk. Journal of Pediatrics 199I; I I 9: 793-798.

32. Hagstrom JN, Walter J, Bluebond-Langner R et al. Prevalence of the factor $V$ Leiden mutation in children and neonates with thromboembolic disease. Journal of Pediatrics 1998; I33: 777-78I.

33. Heller C, Schobess R, Kurnik $\mathrm{K}$ et al. Abdominal venous thrombosis in neonates and infants: role of prothrombotic risk factors-a multicentre case-control study. British Journal of Haematology 2000; I I I: 534-539.

* 34. Nowak-Göttl U, Junker R, Hartmeier M et al. Increased lipoprotein (a) is an important risk factor for venous thrombosis in childhood. Circulation 1999; 100: 743-748.

35. Nowak-Göttl U, Sträter R, Heinecke A et al. Lipoprotein (a) and genetic polymorphisms of clotting factor $\mathrm{V}$, prothrombin and methylenetetrahydrofolate reductase are risk factors of ischaemic stroke in childhood. Blood 1999; 94: 3678-3682.

36. Ehrenforth S, Junker R, Koch HG et al. Multicentre evaluation of combined prothrombotic defects with thrombophilia in childhood. European Journal of Pediatrics 1999; I 58: S97-SI04.

37. Junker R, Koch HG, Auberger K et al. Prothrombin G202 I0A gene mutation and further prothrombotic risk factors in childhood thrombophilia. Arteriosclerosis, Thrombosis and Vascular Biology 1999; 19: 2568-2572.

38. Vielhaber $\mathrm{H}$, Ehrenforth $\mathrm{S}$, Koch $\mathrm{HG}$ et al. Cerebral venous thrombosis in infancy and childhood: role of genetic and acquired risk factors of thrombophilia. European Journal of Pediatrics 1998; I 57: 555-560.

* 39. Canadian Pediatric ischaemic Stroke Study Group, DeVeber G \& Andrew M. Cerebral sinovenous thrombosis in children. New England Journal of Medicine 200I; 345: 4I7-423.

40. Riikonen RS, Vahtera EM \& Kekomäki RM. Physiological anticoagulants and activated protein $C$ resistance in childhood stroke. Acta Paediatrica 1996; 85: 242-244.

4I. Zenz W, Bodo Z, Plotho J et al. Factor V Leiden and prothrombin gene G202 I0A variant in children with stroke. Thrombosis and Haemostasis 1998; 80: 763-766.

* 42. Kenet G, Sadetzki S, Murad H et al. Factor V Leiden and antiphospholipid antibodies are significant risk factors for ischaemic stroke in children. Stroke 2000; 3I: I283-I288.

43. Günther G, Junker R, Sträter R et al. Symptomatic ischaemic stroke in full-term neonates: role of acquired and genetic prothrombotic risk factors. Stroke 2000; 3 I : 246-25I.

44. Laeson SE, Butler D, Enayat MS \& Williams MD. Congenital thrombophilia and thrombosis: a study in a single centre. Archives of Disease in Childhood 1999; 81: 176-178.

45. Bonduel M, Hepner M, Sciuccati $G$ et al. Prothrombotic abnormalities in children with venous thromboembolism. Journal of Pediatric Hematology Oncology 2000; 22: 66-72.

46. Mudd SH, Skovby F, Levy HL et al. The natural history of homocystinuria due to cystathionine- $\beta$-synthase deficiency. American Journal of Human Genetics 1985; 37: I-3I. 
47. Van Beynum IM, Smeitink JA, den Heijer M et al. Hyperhomocysteinemia: a risk for ischaemic stroke in children. Circulation 1999; 99: 2070-2072.

48. Nowak-Göttl U, Junker R, Kreuz $W$ et al. Risk of recurrent thrombosis in children with combined prothrombotic risk factors. Blood 200I; 97: 858-862.

* 49. Manco-Johnson MJ, Nuss R, Key N et al. Lupus anticoagulant and protein S deficiency in children with postvaricella purpura fulminans or thrombosis. Journal of Pediatrics 1996; I 28: 319-323.

50. Andrew M, Paes B \& Johnston M. Development of the hemostatic system in the neonate and young infant. Journal of Pediatric Hematology Oncology 1990; 1 2: 95- 104.

5I. Manco-Johnson MJ, Grabowski EF, Hellgreen M et al. Laboratory testing for thrombophilia in pediatric patients. On behalf of the Scientific Subcommittee on Perinatal and Pediatric Thrombosis of the Scientific and Standardization Committee of the International Society of thrombosis and Haemostasis. Thrombosis and Haemostasis 2002; 88: I243- I 244.

52. Lane DA, Mannucci PM, Bauer KA et al. Inherited thrombophilia: Part 2. Thrombosis and Haemostasis I996; 76: 824-834.

* 53. Häuseler M, Duyue D, Merz U et al. The clinical outcome after inferior vena cava thrombosis in early infancy. European Journal of Pediatrics 1999; 158: 416-420.

* 54. Mocan H, Beattie TJ \& Murphy AV. Renal venous thrombosis in infancy: long-term follow-up. Pediatric Nephrology 1991; 5: 45-49.

55. Bökenkamp A, von Kries R, Nowak-Göttl $U$ et al. Neonatal renal venous thrombosis in Germany between 1992 and 1994: epidemiology, treatment and outcome. European Journal of Pediatrics 2000; I 59: 44-48.

56. Monagle P, Adams M, Mahoney M et al. Outcome of pediatric thromboembolic disease: a report from the Canadian childhood thrombophilia registry. Pediatric Research 2000; 47: 763-766.

57. Monagle P, Michelson AD, Bovill E \& Andrew M. Antithrombotic therapy in children. Chest 200I; I I 9: 344S-370S.

* 58. Massicotte P, Adams M, Marzinotto $\mathrm{V}$ et al. Low molecular weight heparin in pediatric patients with thrombotic disease: a dose finding study. Journal of Pediatrics 1996; I28: 313-318.

59. Dix D, Andrew M, Marzinotto $\vee$ et al. The use of low molecular weight heparin in pediatric patients: a prospective cohort study. Journal of Pediatrics 2000; I36: 439-445.

* 60. Manco-Johnson MJ, Grabowski EF, Hellgreen M et al. Recommendations for tPA thrombolysis in children. On behalf of the Scientific Subcommittee on Perinatal and Pediatric Thrombosis of the Scientific and Standardization Committee of the International Society of thrombosis and Haemostasis. Thrombosis and Haemostasis 2002; 88: $|24|-1242$.

6I. Kirk CR \& Qureshi SA. Streptokinase in the management of arterial thrombosis in infancy. International Journal of Cardiology 1989; 25: 15-20.

62. Nowak-Göttl U, Schwabe D, Schneider W et al. Thrombolysis with recombinant tissue-type plasminogen activator in renal venous thrombosis in infancy. Lancet 1992; 340: 1005.

63. Wever ML, Liem KD, Geven WB \& Tanke RB. Urokinase therapy in neonates with catheter related central venous thrombosis. Thrombosis and Haemostasis 1995; 73: I80-I85.

64. Farnoux C, Camard O, Pinquier D et al. Recombinant tissue-type plasminogen activator therapy of thrombosis in 16 neonates. Journal of Pediatrics 1998; 133: I37- 140.

65. Weiner GM, Castle VP, DiPietro MA \& Faix RG. Successful treatment of neonatal arterial thrombosis with recombinant tissue plasminogen activator. Journal of Pediatrics 1998; I33: I33- 136.

66. Nowak-Göttl U, Auberger K, Halimeh S et al. Thrombolysis in newborns and infants. Thrombosis and Haemostasis 1999; 82: SII2-SII6.

67. Manco-Johnson MJ, Nuss R, Krupski W et al. Combined thrombolytic and anticoagulant therapy for venous thrombosis in children. Journal of Pediatrics 2000; 136: 446-453.

68. Marlar RA, Montgommery R \& Broeckmans AW. Diagnosis and treatment of homozygous protein C deficiency. Journal of Pediatrics 1989; I 14: 528-534.

69. Dreyfus M, Magny JF, Bridey F et al. Treatment of homozygous protein $C$ deficiency and neonatal purpura fulminans with purified protein C concentrate. New England Journal of Medicine 199I; 325: 1565- 1568.

70. Zöhrer B, Zenz W, Rettenbacher $A$ et al. Danaparoid sodium (Orgaran ${ }^{R}$ ) in four children with heparininduced thrombocytopenia type II. Acta Paediatrica 200I; 90: 7657-7677.

7I. Streif W, Andrew M, Marzinotto V et al. Analysis of Warfarin therapy in pediatric patients: a prospective cohort study of 319 patients. Blood 1999; 94: 3007-3014.

72. Straeter R, Kurnik K, Heller C et al. Aspirin versus low-dose low-molecular-weight heparin: antithrombotic therapy in paediatric ischaemic stroke patients: a prospective follow-up study. Stroke 2000; 32: 2554-2558. 